Research Report No. 13/2013

\title{
Moving Backwards: Does the Lack of Duty to Consult Create the Right to Infringe Aboriginal and Treaty Rights?
}

Shin Imai

Osgoode Hall Law School of York University, simai@osgoode.yorku.ca

Ashley Stacey

Follow this and additional works at: http://digitalcommons.osgoode.yorku.ca/clpe

\section{Recommended Citation}

Imai, Shin and Stacey, Ashley, "Moving Backwards: Does the Lack of Duty to Consult Create the Right to Infringe Aboriginal and Treaty Rights?" (2013). Comparative Research in Law \& Political Economy. Research Paper No. 13/2013.

http://digitalcommons.osgoode.yorku.ca/clpe/262 


\section{OSGOODE}

OSGOODE HALL LAW SCHOOL YORK U N I VERSITY

\section{OSGOODE HALL LAW SCHOOL}

Comparative Research in Law \& Political Economy

RESEARCH PAPER SERIES

Research Paper No. 13/2013

\section{Moving Backwards: Does the Lack of Duty to Consult Create the Right to Infringe Aboriginal and Treaty Rights?}

Shin Imai* and Ashley Stacey**

\section{Editors:}

Peer Zumbansen (Osgoode Hall Law School, Toronto, Director Comparative Research in Law and Political Economy)

John W. Cioffi (University of California at Riverside)

Leeanne Footman (Osgoode Hall Law School, Toronto, Production Editor)

*Shin Imai, Associate Professor, Osgoode Hall Law School

**Ashley Stacey, Student at Law, Osgoode Hall Law School 


\section{Moving Backwards: Does the Lack of Duty to Consult Create the Right to Infringe Aboriginal and Treaty Rights?}

Shin Imai* and Ashley Stacey**

January 21, 2013

This is a draft. Please send any comments to Shin Imai at (simai@osgoode.yorku.ca)

* Shin Imai, Associate Professor, Osgoode Hall Law School

** Ashley Stacey, Student at Law, Osgoode Hall Law School 
The duty to consult and accommodate has become one of the most important principles of Canadian Aboriginal law. Since Haida Nation v British Columbia (Minister of Forests), ${ }^{1}$ the Supreme Court of Canada has sought to clarify the boundaries of consultation to ensure that developments affecting Aboriginal rights proceed with a degree of certainty. It is clear that the Crown bears the responsibility for consultation and a failure to consult may result in overturning or staying decisions of the Crown until consultation has taken place. Such consultation is grounded in the honour of the Crown, which is a core constitutional principle informing all interactions between Aboriginal peoples and the government. ${ }^{2}$ However, what happens if an entity that is not the Crown - a municipality or a private business - does not consult? If the entity is authorized by statute to act in ways that infringe the rights of Aboriginal people, what will the courts do?

Two recent cases have addressed this issue. In Neskonlith Indian Band $v$ Salmon Arm (City) ${ }^{3}$ the British Columbia Court of Appeal was asked to decide whether the constitutional duty to consult could be imposed on a municipality. The Court noted that there were powerful arguments "both legal and practical"4 against inferring such a duty on the municipality and found that the project could go ahead because the municipality did not have an obligation to consult. In Wahgoshig First Nation v Solid Gold Resources Corp., ${ }^{5}$ a small mining exploration company ignored provincial government directions to consult with the local First Nation and began exploration activities. While Brown J. at the initial hearing found that Solid Gold failed to consult, leave to appeal was granted by the Divisional Court (per Wilton - Siegel J.) on the basis that Solid Gold may not have had a duty to consult and consequently may have been justified in carrying on the exploration activities.

In both judgments, the analysis focused on whether the particular entity before the Court - the municipality or the mining company - had a duty to consult. The corollary to finding that there was no duty to consult was that the activity in dispute could proceed. Presumably, the Crown

\footnotetext{
${ }^{1} 2004$ SCC 73, [2004] 3 SCR 511 ("Haida Nation").

${ }^{2}$ Ibid at para 16. Rio Tinto Alcan Inc. v Carrier Sekani Tribal Council, 2010 SCC 43, [2010] 2 SCR 650 at para 32 ("Rio Tinto").

${ }^{3} 2012$ BCCA 379, [2012] 4 CNLR 218 (“Neskonlith").

${ }^{4} \mathrm{Ibid}$ at para 66.

${ }^{5} 2012$ ONSC 2323, [2012] OJ No 4363 ("Solid Gold"). See initial decision at Wahgoshig First Nation v Ontario, 2011 ONSC 7708, 108 OR (3d) 647 ("Wahgoshig").
} 
could still have the duty to consult, but the First Nation was left to pursue the Crown's failure to consult in some other forum.

We argue that the two courts asked the wrong question and came to a result that is ultimately not supportable. In our view, the results of an inquiry into who has the duty to consult does not also answer the question about whether consultation is necessary before a project can proceed. These are two separate questions. We believe consultation is akin to a condition precedent to proceeding with a project that actually or potentially infringes Aboriginal rights.

\section{The Duty to Consult and Third Parties: Where There Are No Responsibilities, Carry On...}

In Neskonlith, the City of Salmon Arm authorized the construction of a shopping mall on a flood plain. The project was so dangerous that a hazardous development permit was required pursuant to Part 26 of the British Columbia Local Government Act. ${ }^{6}$ The Neskonlith First Nation bordered on the development and sought to quash this permit as they were concerned with the damage that could result should there be a flood. The First Nation argued that the municipality had a duty to consult. As the provincial Crown had empowered municipalities to make land use decisions, this delegation of power must necessarily have been accompanied by the delegation of the provincial duty to consult. Practically speaking, local governments were in the best position to be able to assess the effects a decision had on First Nations. The relevant excerpt from the Neskonlith Indian Band's factum states:

Local governments, as the decision-makers regarding land use decisions that could affect the exercise of Aboriginal Title and Rights, are in the best position to engage in the consultation process. They are located in the area where the proposed development is proposed to take place and have a better understanding of the local circumstances than centralized governments. ${ }^{7}$

At the initial hearing before the British Columbia Supreme Court, Leask J. reasoned that the duty to consult lay only with the Crown. As municipalities were not the Crown, municipalities did not have such a duty. Since the municipality had the authority to approve the construction of the mall, construction could continue. Leask J. concluded:

[T]he honour of the Crown is non-delegable and the final responsibility for consultation rests at all times with the Crown. Procedural aspects of the duty to

\footnotetext{
${ }_{7}^{6}$ Local Government Act, RSBC 1996, c 323, Part 26 [LGA].

${ }^{7}$ Neskonlith, supra note 3 at para 64.
} 
consult can be delegated, but in order for the province to do so, the power must be expressly or impliedly conferred by statute. ${ }^{8}$

The Court of Appeal upheld Leask J.'s ruling, relying on two main cases to reach its decision. In Haida Nation, where the issue was whether the duty to consult lay with a forestry company, the Supreme Court of Canada said:

The Crown alone remains legally responsible for the consequences of its actions and interactions with third parties that affect Aboriginal interests. The Crown may delegate procedural aspects of consultation to industry proponents seeking a particular development... However, the ultimate legal responsibility for consultation and accommodation rests with the Crown. The honour of the Crown cannot be delegated. ${ }^{9}$

In Rio Tinto Alcan Inc. v Carrier Sekani Tribal Council, ${ }^{10}$ the issue was not whether a private developer had the duty to consult, but whether a regulatory body or tribunal had a duty to consult. Here, the Supreme Court of Canada held that a legislature may delegate its duty to consult but in the absence of express or implied authorization to do so, no such duty existed.

The power to engage in consultation itself, as distinct from the jurisdiction to determine whether a duty to consult exists, cannot be inferred from the mere power to consider questions of law. Consultation itself is not a question of law; it is a distinct and often complex constitutional process and, in certain circumstances, a right involving facts, law, policy, and compromise. The tribunal seeking to engage in consultation itself must therefore possess remedial powers necessary to do what it is asked to do in connection with the consultation. The remedial powers of a tribunal will depend on that tribunal's enabling statute, and will require discerning the legislative intent: ${ }^{11}$

Based on Haida Nation and Rio Tinto, the Court concluded that municipalities lack the authority to engage in the complex constitutional process to consult, as the Province had not expressly delegated such powers.

A similar issue recently arose in Wahgoshig where a mining company, Solid Gold, actively resisted consultation with a First Nation and began exploration activities in spite of being advised by the Crown that they should consult. Solid Gold argued that under the "free entry" provisions of the Mining Act in force at that time, the company had the authority to begin exploration on

\footnotetext{
${ }^{8}$ Neskonlith Indian Band v Salmon Arm (City), 2012 BCSC 499, [2012] BCJ No 677 at para 46.

${ }^{9}$ Haida Nation, supra note 1 at para 53.

${ }^{10}$ Rio Tinto, supra note 2.

${ }^{11}$ Ibid at para 60.
} 
Crown land, without seeking any permit or permission of the Crown. ${ }^{12}$ While the Ontario Superior Court of Justice hearing the injunction application rejected this argument, ${ }^{13}$ Solid Gold's position seemed to be given some credence by a decision of the Divisional Court in the course of granting leave to appeal. Wilton-Siegel J. concluded:

While McLachlin C.J. stated in Haida Nation that third parties may be liable to First Nations, I think it is clear that the statement refers to actions asserted by First Nations against third parties for breach of a duty owed directly by a third party to a First Nation, rather than by the Crown to the First Nation. As such Haida Nation does not support the imposition of a duty to consult on a third party in the absence of an express delegation. ${ }^{14}$

\section{The Who of Consultation Does not Answer the Should of Consultation}

What the British Columbia Court of Appeal in Neskonlith took from Haida Nation and Rio Tinto was that some bodies did not have the obligation to carry out consultations. The consequence of being freed of this constitutional burden meant that there was no longer any constitutional barrier. This is an approach that is familiar in the analysis of the applicability of the Charter of Rights and Freedoms. ${ }^{15}$ The duty to comply with the provisions of the Charter is restricted to the federal and provincial governments by section 32 of the Constitution Act, 1982. ${ }^{16}$ Because private individuals or non-government entities are not bound by the Charter, the character of the entity that is engaging in the activity at issue will determine whether the Charter has any relevance. A private enterprise, for example, will not be bound by the free speech provisions of the Charter in its treatment of its employees. If the Charter does not apply, then the entity may carry on ignoring the restrictions that would have been imposed had the Charter applied.

\footnotetext{
12 Wahgoshig, supra note 5 at paras 22-23. See also Mining Act, RSO 1990, c M 14, ss 19(1), 27. Under the "free entry system" nearly all Crown land, including Aboriginal traditional territory, is open for mining prospecting and staking, without notification or consultation. Under section 19, a prospector could obtain a license as long as they were eighteen years old and paid a fee. A holder of a license could then prospect for minerals and stake out claims on Crown lands pursuant to section 27. The Mining Act was recently amended and contains provisions relating to the consultation of Aboriginal people. Section 19 now requires the completion of an online educational program called the Mining Act Awareness Program, which suggests that consultation occur early in the process. See Mining Act Awareness Program, online: Ministry of Northern Development and Mines <http://www.mndm.gov.on.ca/en/mines-and-minerals/mining-act/mining-act-awareness-program> for program. Also, section 50(2.1) was added and outlines new requirements. Effective as of April 1, 2013, some early exploration activities will require the submission of an exploration plan and the application for an exploration permit, which both require that notice and consultation be provided to affected Aboriginal communities. See Exploration Plans and Exploration Permits, O Reg 308/12, ss 6-7, 13-14 for relevant provisions.

${ }^{13}$ Ibid Wahgoshig at para 41.

14 Solid Gold, supra note 5 at para 33.

${ }^{15}$ Part I of the Constitution Act, 1982, being Schedule B to the Canada Act 1982 (UK), 1982 c 11 [Charter].

${ }^{16}$ s 32, being Schedule B to the Canada Act 1982 (UK), 1982 c 11 ("Constitution").
} 
While there is a widely held perception that Aboriginal rights are listed in the Charter, in fact, this is incorrect. The rights in the Charter are set out under Part I of the Constitution Act, $1982 .{ }^{17}$ Aboriginal peoples' rights are set out in sections 35 and 35.1 in Part II, under the heading "Rights Of The Aboriginal Peoples Of Canada". 18 The restrictions in section 32 only apply to the rights in Part I of the Charter. Unlike breaches of rights mentioned in the Charter, Aboriginal rights under Part II do not provide for a sphere of activity by private actors that is beyond the reach of the constitutional rights. Consequently, answering the question about who has the duty to consult does not answer the question about whether consultation should occur.

Haida Nation is not a case like Retail, Wholesale and Department Store Union, Local $580 v$ Dolphin Delivery ${ }^{19}$ that is focused on the reach of the Charter. Haida Nation addresses fundamental issues concerning the political make up of our nation, the recognition of inherent Aboriginal rights and the reconciliation of Aboriginal and non-Aboriginal people. It is the Crown's sui generis fiduciary duty towards Aboriginal people that has led the Supreme Court of Canada and subsequent courts to view the Crown as a key player to consultation. The basis for this finding is largely rooted in the history of the Crown interposing itself in relationships between individual settlers and Aboriginal people. This was clearly articulated in the Royal Proclamation of $1763,{ }^{20}$ which prohibited the transfer of Aboriginal lands directly to nonAboriginal individuals and required that land be surrendered to the Crown first. This policy was instituted because individual settlers were causing havoc with relations between the Crown and Aboriginal people.

And whereas great Frauds and Abuses have been committed in purchasing Lands of the Indians, to the great Prejudice of our Interests, and to the great Dissatisfaction of the said Indians; In order, therefore, to prevent such Irregularities for the future, and to the end that the Indians may be convinced of our Justice and determined Resolution to remove all reasonable Cause of Discontent, We do, with the Advice of our Privy Council strictly enjoin and require, that no private Person do presume to make any purchase from the said Indians of any Lands reserved to the said Indians... 21

Seen in this light, Haida Nation's insistence that the Crown bear the responsibility for consultation was to continue the legal and historical relationship between the Crown and Aboriginal people. The case was not meant to stand for the proposition that only the Crown was restricted in its ability to infringe Aboriginal rights, while other parties were free to infringe so long as they had legislative authority to do so. The case meant to reinforce the notion that the

\footnotetext{
${ }^{17}$ Charter, supra note 15.

${ }^{18}$ Constitution, supra note 16 , ss $35-35.1$

${ }^{19}$ (1986), [1986] 2 SCR 573, 33 DLR (4th) 174.

${ }^{20}$ See Royal Proclamation (1763), reprinted in RSC 1985, App II, No. 1.

${ }^{21}$ Ibid.
} 
Crown should not be able to shed the responsibilities associated with the honour of the Crown by delegating responsibilities to other parties. Haida Nation must be read together with $R v$ Sparrow, 22 ("Sparrow") which set out ways in which Aboriginal rights could be infringed. Sparrow permitted the Crown to infringe Aboriginal rights guaranteed in section 35 of the Constitution Act, $1982,{ }^{23}$ but only by satisfying certain conditions dictated by the honour of the Crown, including having a proper legislative objective, infringing the right as little as possible, consultation and where appropriate, compensation.

In sum, whether or not a project should proceed should not be decided by whether a particular entity or business has the duty to consult. Rather, the Supreme Court of Canada has decided that the constitutionally permissible manner to affect asserted Aboriginal interest in the land is through the mechanism of consultation by the Crown. If the Crown has failed to consult, then the precondition for taking actions that affect the Aboriginal interest, has not been met. The fact that a municipality or a private business does not have the duty to consult does not put them in a better position than the Crown. Rather, these entities must wait for the Crown to fulfill the precondition before their ability to act comes to life.

\section{The Tail Should Not Wag the Dog ....}

Having said this, we are not suggesting that the decisions about who has the duty to consult in Neskonlith and Wahgoshig are necessarily wrong. In general, we think that the Crown should be responsible for consultation. Neither are we suggesting that consultation is required in every case. If the duty to consult does not arise, then any party with appropriate authority can carry on with its project. However, the British Columbia Court of Appeal hinted that requiring consultation for municipal activities would be unmanageable, and the same concern may have underlay the decision of Wilton-Siegel J. Such concerns are relevant to the development of the law in this area, and so we address three of them below.

(i) Do municipalities have the capacity to consult?

Newbury J. questioned whether a municipality has the necessary infrastructure to actually conduct a consultation.

I also suggest that despite the aspirational wording of s. 1 of the Community Charter noted earlier, municipal governments lack the practical resources to consult and accommodate. Such governments (of which there are 191 in British Columbia) range greatly in size and tax-base, and are generally concerned with the regulation of

\footnotetext{
22 [1990] 1 SCR 1075.

${ }^{23}$ Constitution, supra note 16 , s 35 .
} 
privately-owned land and activities thereon. Crown land and natural resources found thereon remain within the purview of the Province. It is precisely because the Crown asserted sovereignty over lands previously occupied by Aboriginal peoples that the Crown in right of the Province is now held to the duty to consult: ${ }^{24}$

This question seems to be answered in the Neskonlith case itself, as the City of Salmon Arm did take good faith steps to engage the First Nation in the process of reviewing the proposal. The Court of Appeal concluded that, had Salmon Arm been required to consult, the initiatives it undertook would have satisfied the duty.

The Neskonlith were treated respectfully by the City and its staff; they were given copies of all relevant materials; they were heard at various meetings; their expert reports were obviously reviewed with care by the owner's experts; and various modifications, including the reduction of the development to only 20 acres, were made by Shopping Centres to its plans in the process. ${ }^{25}$

Therefore, it can hardly be argued that all municipalities do not have the appropriate infrastructure. For those who do not have the infrastructure, however, there must be provincial mechanisms for addressing the gap, as provincial legislation requires local governments in British Columbia to engage in general community consultations. The Local Government Act also requires that, in preparing official community plans, a local government must consider whether consultation is required with First Nations. The relevant section states:

879. (1) During the development of an official community plan, or the repeal or amendment of an official community plan, the proposing local government must provide one or more opportunities it considers appropriate for consultation with persons, organizations and authorities it considers will be affected.

(2) For the purposes of subsection (1), the local government must

(a) consider whether the opportunities for consultation with one or more of the persons, organizations and authorities should be early and ongoing, and

(b) specifically consider whether consultation is required with

(iv) first nations ${ }^{26}$

In conclusion, we note that municipalities do engage in consultation on other issues. The location of social housing in a neigbourhood, the decision to license a casino or the creation of a waste disposal site can result in an extensive process of consultation with citizens that can last for years.

\footnotetext{
${ }^{24}$ Neskonlith, supra note 3 at para 71.

${ }^{25}$ Ibid at para 89.

${ }^{26}$ LGA, supra note 6, s 879 .
} 
In the case of consultation with Aboriginal people, the Neskonlith case itself shows that a broad brush approach to capacity is not appropriate, as some, and perhaps all, municipalities clearly do have the capacity to consult.

(ii) Is there a danger that every minor issue would need to be the subject of consultation, spawning endless litigation?

Newbury J. was worried that every decision made by a municipality ranging from the issuance of business licenses to the designation of parks would require consultation. ${ }^{27}$ This is indeed an issue, and the Court notes:

Daily life would be seriously bogged down if consultation -- including the required "strength of claim" assessment -- became necessary whenever a right or interest of a First Nation "might be" affected. In the end, I doubt that it would be in the interests of First Nations, the Crown or the ultimate goal of reconciliation for the duty to consult to be ground down into such small particles, obscuring the larger "upstream" objectives described in Haida. ${ }^{28}$

The Supreme Court of Canada has said that the content of the duty to consult varies on a spectrum depending on specific circumstances. ${ }^{29}$ This is based on a preliminary assessment of the strength of the asserted Aboriginal right or title and the seriousness of the potential adverse effects on such a right. ${ }^{30}$ At the low end, where the claim is weak or infringement is minor, the Crown may only be required to "give notice, disclose information, and discuss issues raised in response to the notice" ${ }^{31}$ but requires little more. It is only in the case of a strong prima facie claim that a deeper consultation will be required, aimed at finding interim solutions with the possibility of accommodation. ${ }^{32}$

Further, not every decision requires consultation. The duty to consult arises when there is a potential that the contemplated conduct may adversely affect the asserted right in question. ${ }^{33}$ Merely "speculative" impacts will not trigger consultation. ${ }^{34}$ Decisions which do not have an impact on Aboriginal or treaty rights are not the subject of consultation: The claimant must show a causal relationship between the proposed government conduct or decision and a potential for adverse impacts on pending Aboriginal claims or rights. ${ }^{35}$

\footnotetext{
${ }^{27}$ Neskonlith, supra note 3 at para 72.

28 Ibid.

${ }^{29}$ Haida Nation, supra note 1 at para 43.

${ }^{30}$ Ibid at para 39.

${ }^{31}$ Ibid at para 43.

32 Ibid at paras 44, 47.

${ }^{33}$ Ibid at para 35.

${ }^{34}$ Rio Tinto, supra note 2 at para 46.

${ }^{35}$ Ibid at para 45.
} 
Newbury J. also expressed concern about municipalities having to engage in an initial strength of claim assessment whenever an Aboriginal right was affected. It is unclear whether the City engaged in an initial assessment. ${ }^{36}$ In any case, such an assessment would have been aided by the report describing the First Nations' strong economic ties and ecological values to their affected traditional territory, which was provided to the City and the project proponent by the affected First Nation themselves. This makes sense given that the First Nation possesses special Indigenous knowledge and is in the best position to provide evidence of the strength of their asserted Aboriginal title. The community consultation scheme provided in the Local Government Act also allowed the City to assess the strength of the potential adverse effects. Therefore, assessing the strength of the claim should not pose any concern to a municipality who would likely be provided the necessary information by the affected parties. This is consistent with McLachlin C.J.'s statement in Haida, that Aboriginal claimants ought to bring forward and outline their claims by including the scope and nature of their asserted Aboriginal rights and the alleged infringements. ${ }^{37}$

It may, in fact, be true that there will be a period when litigation will appear to increase, as different parties attempt to define the scope of the duty on municipalities. However, it is also true that, once there have been a few cases that determine the parameters of the duty to consult at the municipal level, the litigation will die down, and focus on the most contentious cases. It is important to remember that preventing disputes from coming to a court of law will not prevent disputes from arising - disputes that will be addressed through other channels.

(iii) Do mining companies have the capacity to consult?

In the Wahgoshig case, the issue of whether mining companies have the capacity to consult did not really arise because most mining companies - of all sizes - do consult as part of industry standards for responsible mining practices. However, Wilton-Siegel J. in Solid Gold, may have been worried that it was inappropriate to burden mining companies with the duty to consult before engaging exploration. In the initial decision, the Court made note that it appeared Solid Gold was not following the guidelines set forth by the Prospectors and Developers Association of Canada. ${ }^{38}$ Part of the guidelines includes a provision dealing with the consultation of Indigenous peoples:

\footnotetext{
${ }^{36}$ Neskonlith, supra note 3 at para 88. The Neskonlith took the position that the City did not conduct an assessment of their claim since it (the City) believed that municipalities were under no duty to consult. The Court held this was irrelevant and relied on Beckman v Little Salmon/Carmacks First Nation, [2011] 1 CNLR 12 at para 39 where the Territorial government fulfilled the duty to consult even though it did not consider itself to have such a duty.

${ }^{37}$ Haida, supra note 1 at para 36.

${ }^{38}$ Wahgoshig, supra note 5 at para 59.
} 
In all dealings with communities (see also Principle 5), explorers are encouraged to:

a. Respect the rights and interests of local communities affected by exploration activities and the rights of indigenous and tribal peoples and communities consistent with international human rights standards...

f. Consult with the affected community and appropriate levels of government to identify strategies to effectively manage the social consequences of exploration and potential development of a mine; ${ }^{39}$

Principle 5 of the guidelines further stresses the need to engage affected Indigenous people on the basis that "respect, transparency, consultation and participation is fundamental to obtaining the social license that underpins the success of an exploration project". ${ }^{40}$ In reality, according to the guidelines, there are concrete reasons to do so:

Experience has shown that, if there is active engagement with stakeholders from the earliest stage of exploration and greater accommodation of local concerns and community participation in decision making, there is a concomitant decrease in the risk of social conflict. ${ }^{41}$

Industry standards such as these have been criticized for being ineffective because they cannot be enforced. Nonetheless, some companies adhere to these standards and Wahgoshig First Nation has agreements with other resource extraction companies. ${ }^{42}$ For example, the Impact Benefit Agreement with Detour Gold stipulates the company's commitment to consultation. ${ }^{43}$ While courts at this point may not be able to sanction companies who breach these standards, it does seem odd that the courts would undermine these standards by giving a competitive advantage to companies like Solid Gold who refused to consult.

Solid Gold raised a concern about being placed in serious financial jeopardy if it could not continue with its drilling as it was under financial pressure caused by the necessity to maximize tax advantages through the use of flow-through shares. Specifically, funds were required to be

\footnotetext{
${ }^{39}$ Principles \& Guidance, online: e3 Plus- a Framework for Responsible Exploration <http://www.pdac.ca/e3plus/> at 12.

40 lbid at 16.

${ }^{41}$ Ibid at 16.

${ }^{42}$ See Agreements Between Mining Companies and Aboriginal Communities or Government, online: Natural Resources Canada <http://www.nrcan.gc.ca/minerals-metals/sites/www.nrcan.gc.ca.mineralsmetals/files/files/pdf/abor-auto/aam-eac-e2012.pdf> for the various types of agreements reached between mining companies and the Wahgoshig First Nation.

${ }^{43}$ Detour Gold and Wahgoshig First Nation Sign Impact Benefit Agreement for Detour Lake Project, online: Wahgoshig First Nation < http://wahgoshigfirstnation.com/detour_gold_and_wahgoshig_first_nation_sign_agreement.html>.
} 
expended by year end or significant penalties would be imposed. ${ }^{44}$ However, the concerns of speculators seeking a quick profit cannot drive the relationship between Aboriginal people and Canada. We would argue that the reasoning behind Haida Nation was to require consultation precisely to prevent the exigencies of short term profit speculation in natural resources from damaging relations with Aboriginal people.

\section{Conclusion}

The honour of the Crown lies at the heart of Canada's relationship to Aboriginal people. It is embedded in Canadian history and permeates the law today. Sparrow sets out the framework for recognizing and respecting the rights of Aboriginal people, but also the means for infringing those rights. Infringements are not to be taken thoughtlessly, and require the Crown to satisfy conditions that are consistent with the honour of the Crown. Haida Nation elaborated on the implementation of the Sparrow principles in relation to potential infringements of asserted Aboriginal rights.

In Neskonlith and Wahgoshig, the Courts were concerned about the imposition of the duty to consult on non-Crown entities. While there are legitimate questions about which entity has the responsibility for consultation, these concerns should not be addressed by abridging the right to be consulted, nor by doing an end run around protections against infringements of Aboriginal rights.

\footnotetext{
${ }^{44}$ Wahgoshig, supra note 5 at para 67.
} 